\title{
MENGGAPAI TUJUAN BELAJAR SEJARAH, MENGGAPAI BERPIKIR YANG HISTORIS
}

\author{
Muhammad Firnanda \\ Email: 1810111210033@ulm.ac.id \\ Program Studi Pendidikan Sejarah Fakultas Keguruan dan Ilmu Pendidikan \\ Universitas Lambung Mangkurat \\ Banjarmasin
}

\begin{abstract}
Abstrak
Sejarah merupakan hal yang menyenangkan, namun dalam pembelajaran masih mengalami permasalahan. Pembelajaran sejarah dianggap kurang menarik dan banyak menghafal. Dalam pembelajaran sejarah bertujuan untuk menumbuhkan rasa nasionalisme untuk menciptakan jati diri bangsa. Hal yang harus diperhatikan dalam pembelajaran sejarah adalah memahami konsep-konsep utama sejarah dan menguasai keterampilan dasar sejarah. Pembelajaran sejarah pada kurikulum 2013 diarahkan pada upaya melatih siswa untuk mampu berpikir historis. Keterampilan berpikir historis berorientasi seperti penelitian sejarah oleh sejarawan, mendesain pembelajaran sejarah termasuk membuat evaluasinya. Berpikir historis tercapai dengan berpikir yang kritis.
\end{abstract}

\section{PENDAHULUAN}

Sejarah bukanlah sekedar pengetahuan masa lalu yang tidak menarik dan tidak menyenangkan. Menurut Rowse (2014, p. 29) kesenangan paling nyata, mungkin paling menarik dari sejarah adalah bagaimana pengetahuan sejarah memperkaya dan melengkapi penghargaan kita terhadap dunia yang kita lihat di sekeliling kita. Pada umumnya, Simon memiliki menunjukkan bahwa tujuan pembelajaran baru-baru ini bergeser dari kemampuan mengingat informasi (surface learning) untuk dapat menemukan dan menggunakannya (deep learning) (Wirth \& Perkins, 2008, p. 10). 
Pembelajaran sejarah di sekolah dianggap menempatkan peserta didik sebagai pusat pembelajaran dan materi yang disampaikan hanya bersifat hafalan. Menurut Anis (2015) hafalan yang harus diingat oleh siswa berisikan sederatan nama tokoh dan tanggal serta tahun sebuah peristiwa monumental yang mungkin tidak berarti apa-apa bagi siswa, sehingga kemampuannya hanya sebatas itu. Kemudian menurut Sayono (2013, p. 9) persoalan klasik pembelajaran sejarah di sekolah adalah adanya image yang sangat kuat di kalangan siswa bahwa mata pelajaran sejarah adalah mata pelajaran yang bersifat hafalan, kurang menarik, dan membosankan. Hal ini mengakibatkan siswa merasa pembelajaran kurang menyenangkan sehingga kesulitan memahami konsep. Padahal dalam langkah merencanakan pembelajaran harus memperhatikan pengalaman belajar. Belajar bukan sekedar untuk mencatat serta menghafal, namun merupakan proses berpengalaman (Agung \& Wahyuni, 2013, p. 19).

\section{TUJUAN BELAJAR SEJARAH \& BERPIKIR HISTORIS}

Tidak ada kata akhir dalam mempelajari sejarah karena sejarah bersinggungan dengan kehidupan, terutama kehidupan manusia di masyarakat (Rowse, 2014). Dalam Pembelajaran sejarah, belajar sejarah diharapkan mampu meningkatkan nasionalisme dan cinta tanah air. Pembelajaran sejarah mengandung tugas menanamkan semangat berbangsa dan bertanah air (Aman, 2011, p. 2). Sehingga tercipta jati diri bangsa. Menurut Zaenal Arifin Anis (2020) salah satu unsur penting dalam jati diri suatu bangsa adalah kesadaran sejarah secara subjektif.

Hamid Hasan menjabarkan prinsip yang perlu diperhatikan dalam pembelajaran sejarah adalah mengembangkan proses pembelajaran untuk mengembangkan kemampuan dan keterampilan peserta didik dalam memahami konsep-konsep utama sejarah, menguasai keterampilan dasar sejarah, dan memantapkan penggunaan konsep utama dan keterampilan dasar ketika mereka mempelajari berbagai peristiwa sejarah, dan setiap peristiwa sejarah dirancang sebagai kegiatan pembelajaran satu semester dan bukan kegiatan satu pokok bahasan (Umamah, 2014). 
Pembelajaran sejarah pada kurikulum 2013 diarahkan pada upaya melatih siswa untuk mampu berpikir historis (historical thinking skill). Kita semua sudah akrab dengan slogan populer bahwa sekarang ini adalah era berpikir ilmiah, tetapi masyarakat kurang menyadari bahwa era ini tidak lebih dari era berpikir historis. Rowse dalam pendahuluan kuku Apa Guna Sejarah? (2014), mengatakan dalam sejarah bisa ditemukan, sedikit banyak, relasi subjek dan materi, verifikasi atau kontradiksi. Artinya ada yang membuat berpikir kritis, berpikir kritis dalam sejarah adalah berpikir historis.

Abbas (2017, p. 313) menyatakan pembelajaran sejarah merujuk disiplin ilmu sejarah berarti menerapkan berpikir historis (berpikir sejarah). Berpikir historis merujuk kepada cara berpikir kronologis, periodisasi, kausalitas, dan diakronik dan sinkronik. Menurut Maulana (Anis et al, 2020) keterampilan berpikir historis berorientasi seperti sejarawan yang meneliti sejarah, mendesain pembelajaran sejarah termasuk membuat evaluasinya.

Kemdikbud (Abbas, 2017, p. 313) menyebutkan berpikir historis sebagai metode berpikir keilmuan (ilmiah) dalam Kurikulum 2013 dikembangkan melalui pendekatan saintifik menyandarkan pembelajaran pada pendekatan ilmiah melalui penalaran induktif dan penalaran deduktif. Pembelajaran dibangun atas asas bangun logika dengan kritis (berpikir kritis) dan analitik. Menurut Seixas (Anis et al, 2022) Studi tentang hubungan antara berpikir kritis telah berkembang, kemudian bergeser ke studi yang lebih menitikberatkan pada pemikiran sejarah.

Berpikir kritis sebagai langkah awal berpikir historis adalah bentuk ketajaman berpikir untuk menganalisa suatu hal. Tidak mungkin rasanya bisa sampai untuk berpikir historis jika tidak kritis, banyak sekali hal yang menjadi pertanyaan untuk berbagai pikiran di dalam cara berpikir historis/sejarah (cara berpikir kronologis, periodisasi, kausalitas, dan diakronik, dan sinkronik).

\section{SIMPULAN}

Pembelajaran sejarah dianggap tidak menarik dan penuh hafalan padahal pembelajaran sejarah adalah pembelajaran penuh makna dengan 
tujuan belajar menanamkan semangat bangsa (khususnya). Dalam mencapai tujuan dan arahnya, pembelajaran sejarah berorientasi pada keterampilan berpikir historis seperti yang dilakukan sejarawan. Berpikir historis adalah cara berpikir kronologis, periodisasi, kausalitas, dan diakronik, dan sinkronik, tentu diperlukan sebuah pikiran yang kritis. Berpikir historis ini sejalan dengan tujuan kurikulum 2013, yakni berpikir ilmiah. Artinya dengan menggapai tujuan belajar sejarah dengan baik, maka tercapai cara berpikir historis. 


\section{REFERENSI}

Agung, L., \& Wahyuni, S. (2013). Perencanaan Pembelajaran Sejarah. Yogyakarta: Ombak.

Abbas, W. E. (2017). Pendidikan Sejarah, Patriotisme \& Karakter Bangsa; Malaysia-Indonesia. FKIP UNLAM Press.

Sayono, J. (2013). Pembelajaran Sejarah di Sekolah: Dari Pragmatis ke Idealis. Jurnal Sejarah dan Budaya, 7(1), 9-17.

Anis, M. Z. A. (2015). Sejarah Bukan Warisan Melainkan Pembelajaran.

Zaenal Arifin Anis, M. (2020). Obyek Sejarah, Jatidiri Bangsa dan Ketahanan Nasional.

Umamah, N. (2014). Kurikulum 2013 Kendala yang Dihadapi Pendidik dalam Merancang Desain Pembelajaran Sejarah Prosiding Seminar Nasional Pembelajaran Sejarah di Tengah Perubahan. Malang: Fakultas IImu Sosial Universitas Negeri Malang.

Anis, M. Z. A., Putro, H. P. N., Susanto, H., \& Hastuti, K. P. (2020). Historical Thinking Model in Achieving Cognitive Dimension of Indonesian History Learning. PalArch's Journal of Archaeology of Egypt/Egyptology, 17(7), 7894-7906.

Anis, M. Z. A., et al. (2021). Historical Learning Through The Historical Thinking Learning Model (MPBH) Based On Issue Centered History Brings Students Can Think Critical Thinking Reality And Expectations. Jurnal Socius, 10(1), 1-11.

Wirth, K. R., \& Perkins, D. (2008). Learning to learn 